\title{
The Production-oriented Approach to Teaching English Majors' Oral English in Higher Vocational Colleges
}

\author{
Ting Deng \\ English Department, Sichuan Vocational and Technical College \\ Sichuan Vocational and Technical College \\ Suining, Sichuan \\ 408291057@qq.com
}

\begin{abstract}
Many teaching practices have proved that Production-oriented Approach (POA) by Professor Wen Qiufang is good for teaching English in universities and colleges. This article studies the application of POA to teaching English majors' oral English in higher vocational colleges. Starting from general introduction of POA, the article then analyzes the reasons and measures for applying POA to teaching oral English for English majors in higher vocational colleges.
\end{abstract}

Keywords: Production-oriented Approach, oral English teaching, higher vocational college, English majors

\section{INTRODUCTION}

Production-oriented Approach (POA) is a new and effective teaching method specially designed for teaching university students English in China. With the guidance of POA, many scholars have achieved great progress in improving listening, speaking, reading, writing and translating of university students whose English is relatively good. Some other scholars find that POA is also useful for teaching college English in vocational colleges, where the students are not so good at English. And in this article, the author studies the application of POA to teaching English majors' oral English in higher vocational colleges, which has not been studied by others until now.

Oral English is very important for university students and college students, and it is much more important for English majors. But in higher vocational colleges, the traditional oral English teaching method has met many problems, which need to be solved urgently. The author hopes that this article can help teachers to improve English majors' oral English teaching in higher vocational colleges.

\section{THE GENERAL INTRODUCTION OF PRODUCTION-ORIENTED APPROACH}

Many foreign language teaching methods were put forward in 1970s, so that some scholars thought foreign language teaching methods had entered into post-method era since 1990s, which means almost no new teaching method would come, at least for a predictable long time. But in 2015, Wen Qiufang, Professor at Beijing Foreign Studies University put forward Production-oriented Approach (POA). Taking the Input Hypothesis of Swain as the theoretical basis, Professor Wen put forward output-driven hypothesis in 2007, and the hypothesis was developed into output-driven, input-enable hypothesis in 2014, and finally became Production-oriented Approach in 2015. POA aims at improving Chinese adult L2 learners' English ability by emphasizing its teaching principles: Product-oriented principle, learning-centered principle, and whole-person education principle. Instead of the traditional teaching process: input $\rightarrow$ output, POA advocates output $\rightarrow$ input $\rightarrow$ output. Table 1 indicates there are three phases in the teaching process of POA: motivating, enabling and assessing. In motivating phase, with output-driven hypothesis as reference, teachers should design reasonable output task, so as to help students find out their own weak points. In enabling phase, with reference to input-enable hypothesis and selective learning hypothesis, teachers should choose good input material and guide students to learn the input material effectively and selectively. And in assessing phase, with reference to assessment-promote-learning hypothesis, teachers should assess students' performance comprehensively, so that the students can be clear about their strength and shortcomings, their progress and direction of efforts. The following is the theoretical system of POA.

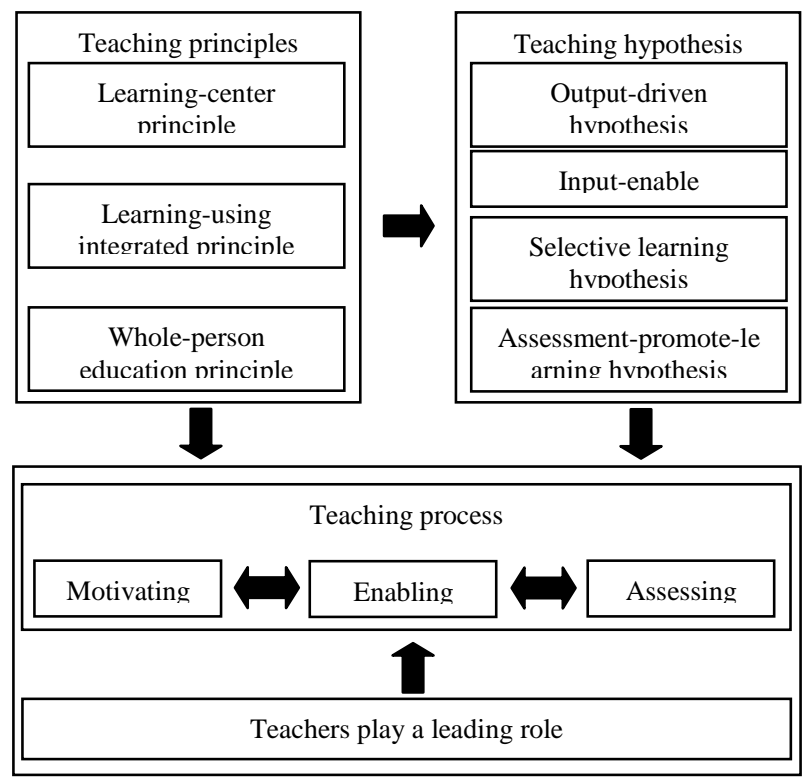

Figure 1. The theoretical system of POA 
As shown in the table1, POA is made up of three components: teaching principles, teaching hypothesis, and teaching process. Teaching principles, which contains learning-center principle, learning-using integrated principle, and whole-person education principle, are the theoretical guidance. Teaching hypothesis, which was made up of output-driven hypothesis, input-enable hypothesis, selective learning hypothesis, and assessment-promote-leaning hypothesis, are the theoretical basis. Teaching process, which includes three phases: motivating, enabling, and assessing, during which teachers play a leading role.

\section{THE REASONS FOR APPLYING PRODUCTION-ORIENTED APPROACH TO COLLEGE ORAL ENGLISH TEACHING}

\section{A. Learning-centered Principle is more Suitable for Teaching Oral English.}

Teacher-oriented teaching mode was prominent in early English classes. It was not a good teaching mode because it neglected students' learning in class, and put too much emphasis on teaching. As a result, the class efficiency was very low because students lack of passion and practice. At the end of $20^{\text {th }}$ century, students-oriented teaching mode was introduced and has been widely applied in university and college English teaching since then. But it also has its disadvantages, for it neglects teachers' important roles as organizers, controllers, promoters, collaborators and evaluators, etc. Both teacher-oriented teaching mode and students-oriented teaching mode neglects the important of leaning, which is the real center in class according to POA. Learning-centered principle values the important roles of both teachers and students, and takes effective learning as the final purpose in English class. Therefore, learning-centered principle is more suitable for teaching oral English.

\section{B. Textbook-centered Principle has Obvious Restrictions}

It is common that college teachers give oral English class basing on textbooks, which may be a good way to guide students practice topical words, phrases and sentences again and again, but it is too boring and mechanical. The students recite words, phrases and sentences mechanically with much effort but they seldom use them in real context. In other words, textbook-centered principle neglects the combination of input and output. As a result, students' English productive competence can't be improved effectively. Both college teachers and students should be aware that there is so much information updated everyday in such an information era, and the teaching contents should not be limited by textbooks and should be updated along with the new information. Oral English textbooks can be considered as a clue, the teacher should add the latest information or hot topics to teaching materials so as to motivate students to learn and apply the input materials.

\section{The Widely Adopted PPP Teaching Method has Met its Bottleneck}

In the classes with PPP teaching method as the guidance, the students usually get input materials passively, and they don't want to select the difficult and important points for themselves, as a result, the class efficiency would be very low. While in motivating phase of POA, the students can make clear their own weak points and they can select and learn the useful input materials according to their own situation in enabling phase. In this case, the class efficiency would be greatly improved.

\section{Learning has always be Separated from Using in Traditional Oral English Class}

Most teachers think that the students can use new words and expressions in their oral English if they listened or read them in class. So listening and reading take much time in class. When scholars called for using English in class, the well-known task-based teaching method found a place in oral English teaching, but it neglects the importance of teaching. These teaching methods mentioned above are typical separation of learning and using. The fact is that there is an interval between input and output, during which the teachers should play a leading role and guide the students to improve their oral English in the process of using. In oral English class, learning a new word means to know its spelling, pronunciation, meaning, and more importantly, to know how to use it in real context. Learning-using integrated principle of POA requires students to integrate learning with using with effective help of teachers, which can help students improve English productive competence.

\section{E. The Traditional Assessment is too Narrow and Limited.}

Most of the assessments for oral English class are based on an interview or an oral communicative at the end of semester. This kind of assessments can not reflect students' performance and progress for a whole semester. But assessing of POA is much more comprehensive than the general assessing method. Assessing of POA is not an assessment of the final test, but an assessment of the whole learning process of students. It includes the assessments of students' participation in the class, the acquisition of English productive competence, and critical thinking skills, and product quality. This comprehensive assessing can enable students to fatherly improve themselves in an all round way.

\section{THE APPLICATION OF PRODUCTION-ORIENTED APPROACH TO TEACHING ENGLISH MAJORS ORAL ENGLISH IN HIGHER VOCATIONAL COLLEGES}

As shown in table 1, teaching process of POA includes three phases, and each phase has different teaching tasks, contents and goals. In this part of article, the author will talk about the application of POA to oral English class for English majors in higher vocation colleges. 


\section{A. The Application of Production-oriented Approach to Motivating}

On the theoretical basis of output-driven hypothesis, teachers should firstly motivate students' learning interest by presenting the related communicative scenes. In order to make students know their production task and language points to master in the class, the prepared communicative scenes should be a little difficult but understandable for students. Besides, they can be a piece of video or audio, a PPT, a micro-lesson, etc. related to the production task, which can be learned by the students in advance with their mobile phones. Then, there should be a task for students to try producing the output task, so as to make them know the production task is not easy and find their own weak points at the same time. This is also a preparation for enabling phase. At last, teachers should clearly tell the students the teaching aims and their production task. Since students in higher vocational colleges have obvious different English levels, students' production task may be different. More difficult production task is for quick students, while easier tasks for slow ones. The detailed tasks and goals of motivating are briefly shown in table I.

TABLE I. TEACHING TASKS, REQUIREMENT AND GOALS OF MOTIVATING

\begin{tabular}{|l|l|l|}
\hline \multicolumn{1}{|c|}{ Tasks } & \multicolumn{1}{|c|}{ Requirements } & \multicolumn{1}{c|}{ Goals } \\
\hline $\begin{array}{l}\text { Teachers present } \\
\text { the communicative } \\
\text { scenes }\end{array}$ & $\begin{array}{l}\text { The scenes should be } \\
\text { related to product task, } \\
\text { logical, difficult but } \\
\text { understandable }\end{array}$ & $\begin{array}{l}\text { Arouse students } \\
\text { interesting }\end{array}$ \\
\hline $\begin{array}{l}\text { Students try } \\
\text { producing output } \\
\text { tasks }\end{array}$ & $\begin{array}{l}\text { Teachers survey the } \\
\text { quality of trial for } \\
\text { students with different } \\
\text { English levels }\end{array}$ & $\begin{array}{l}\text { Students find their } \\
\text { own weak points; } \\
\text { Teachers learn the } \\
\text { students' situations }\end{array}$ \\
\hline $\begin{array}{l}\text { Teachers announce } \\
\text { teaching aims and } \\
\text { output task }\end{array}$ & $\begin{array}{l}\text { The tasks should be } \\
\text { clearly; }\end{array}$ & $\begin{array}{l}\text { Different tasks for } \\
\text { students with different } \\
\text { English levels }\end{array}$ \\
\hline
\end{tabular}

\section{B. The Application of Production-oriented Approach in} Enabling

Enabling is a very important phase, which involves teachers leading and students' learning and using. There is no precedent order between teacher's leading and students' learning and using. Teachers' leading role runs through the whole process of students' learning and using.

In order to improve students' English productive competence efficiently, the enabling activities should be accurate, gradual and various. To be accurate means teachers' enabling activities should be in line with production task and can help students solve their different problems. To be gradual means teachers' enabling activities should start from words and phrases, to sentence, and then to passages. It also means that teachers should reduce their help for students gradually. To be various means that the enabling activities should require students to output different kinds of products, such as monologue, role-play, group work, debate, speech, story, jokes, and so on.
The students should stick to learning-using integrated principle throughout enabling phase. They can learn the input materials from teachers, learn related knowledge form classmates through pair work or group work, and they can also activate their own inert knowledge. With so much to learn, students should select and learn the most suitable knowledge for themselves with the help of teachers to improve their English productive competence. The detailed tasks and goals of enabling are briefly shown in table II.

TABLE II. TASKS, REQUIREMENTS AND GOALS OF ENABLING

\begin{tabular}{|c|c|c|}
\hline Tasks & Requirements & Goals \\
\hline $\begin{array}{l}\text { Teachers deal } \\
\text { with input } \\
\text { materials }\end{array}$ & $\begin{array}{l}\text { Teachers' leading role should } \\
\text { be accurate, gradual and } \\
\text { various }\end{array}$ & \multirow{3}{*}{$\begin{array}{lr}\text { Improve } & \text { teaching } \\
\text { efficiency; } & \\
\text { Enable } & \text { students } \\
\text { Produce } & \text { output } \\
\text { tasks; } & \\
\text { Improve } & \text { students } \\
\text { English productive } & \text { competence }\end{array}$} \\
\hline $\begin{array}{l}\text { Students } \\
\text { practice } \\
\text { sub-tasks }\end{array}$ & $\begin{array}{l}\text { Learning-using integrated } \\
\text { hypothesis } \\
\text { Selective leaning hypothesis }\end{array}$ & \\
\hline $\begin{array}{l}\text { Students } \\
\text { product output } \\
\text { task }\end{array}$ & $\begin{array}{l}\text { Can be finished after class } \\
\text { and be checked next class }\end{array}$ & \\
\hline
\end{tabular}

TABLE III. ASPECTS, METHODS, GOALS AND CATEGORIES OF ASSESSING

\begin{tabular}{|c|l|l|l|}
\hline Aspects & \multicolumn{1}{|c|}{$\begin{array}{c}\text { Detailed } \\
\text { aspects }\end{array}$} & \multicolumn{1}{|c|}{ Methods } & Categories \\
\hline Participation & $\begin{array}{l}\text { Learning } \\
\text { initiative } \\
\text { Concentration } \\
\text { Production } \\
\text { practice }\end{array}$ & $\begin{array}{l}\text { Observing } \\
\text { interview }\end{array}$ & $\begin{array}{l}\text { Instant } \\
\text { assessment }\end{array}$ \\
\hline Progress & $\begin{array}{l}\text { Productive } \\
\text { competence } \\
\text { Critical thinking } \\
\text { skills } \\
\text { Words, } \\
\text { collocations and } \\
\text { grammars }\end{array}$ & $\begin{array}{l}\text { Oral } \\
\text { communication }\end{array}$ & $\begin{array}{l}\text { Delayed } \\
\text { assessment }\end{array}$ \\
\hline Quality & $\begin{array}{l}\text { Communicative } \\
\text { effect } \\
\text { Application of } \\
\text { target words, } \\
\text { collocations and } \\
\text { grammars }\end{array}$ & $\begin{array}{l}\text { Oral } \\
\text { communication }\end{array}$ & $\begin{array}{l}\text { Test papers } \\
\text { assessment }\end{array}$ \\
\hline
\end{tabular}

C. The Application of Product-oriented Approach to

Assessing

Assessing is not the final phase of POA. A comprehensive assessment starts from motivating phase, and lasts to the end. Assessing of POA is not a final test at the end of terms. It should include assessments in at least three broad aspects, namely students' participation in class, students' progress and the quality of students' product. When assessing students' participation in class, teachers should take students' learning initiative, their concentration and their production practice into consideration, and give students a reasonable assessing. When assessing students' progress, teachers should comprehensively assess students' progress in English productive competence, in critical thinking skills, as well as in English words, collocations and grammars. When assessing students' product quality, teachers should analyze 
the communicative effect and the application of target words, phases and sentences. In assessing phase, teachers can use observing, interviewing, test papers and oral communicative as the basic methods. POA divides assessment into two categories, instant assessment and delayed assessment. The former refers to the one assessed by teachers in the process of selective learning instantly, which helps teachers adjust the teaching progress accordingly. The later refers to not to assess until students finish the tasks. The most important goals of such a comprehensive and detailed assessment is to comprehensively reflect students' performance in oral English class and to fatherly promote students' learning.

\section{V.SUMMARY}

After the study, the author finds that it is necessary to change the traditional oral English teaching method for English majors in higher vocational colleges, and POA can greatly motivate students' interest and improve class efficiency, but there still exists some problems to be solved in applying POA to teaching English majors' oral English in higher vocational colleges. For example, there hasn't been an excellent oral English text book, and the preparation task for a class is very heavy at the first beginning. The author hopes that these problems will soon be solved along with the joint efforts of all the scholars and experts.

\section{ACKNOWLEDGMENT}

This article is one of the research achievements of the project research The Application of Production-oriented Approach (POA) to Teaching Oral English for English Majors in Higher Vocational Colleges (18SB0701), funded by Sichuan Provincial Education Department and Sichuan Vocational and Technical College.

\section{REFERENCES}

[1] Wen, Q. F. 2016. The Productuin-oriented approach to teaching university students English in China [J]. Language Teacing. Available on CJO 2016 doi: 10.1017/s026144448160000/x

[2] Wen, Q. F. 2017. The Production-oriented approach: A Pedagogical innovation in university English teaching in China [A]. In L. Wong \&K. Hyland (eds.). Faces of English: students, Teachers, and Pedagogy [C]. London \&New York: Routledge, 91-106.

[3] Wen, Qiufang, Production-oriented Approach to Teaching Chinese Adult Learners $[R]$. A keynote speech at the $7^{\text {th }}$ International Conference on English Language Teaching in China. October 23-26, Nanjing, China

[4] Swain. M. Three Functions of Output in Second Language Learning [A]. In G. Cook \& B. Seidhofer (eds.). Principles and Practice in Applied Linguistics: Studies in Honor of H.G Widdowson [C]. Oxford: OUP. 1995, 125-144Li Jun. The Application of Production-Oriented Teaching Approach in Oral English Teaching for Non-English Majors [D].Shanxi: North University Of China. 2016. 